Hypothesis

\title{
The Role of Corporate Social Responsibility Perceptions in Brand Equity, Brand Credibility, Brand Reputation, and Purchase Intentions
}

\author{
Shu Wang ${ }^{1}$, Ying-Kai Liao ${ }^{2, *}$ D, Wann-Yih $\mathrm{Wu}^{1}$ and Khanh Bao Ho Le ${ }^{1}$ \\ 1 Department of Business Administration, Nanhua University, Chiayi County 62249, Taiwan; \\ wangshu19790202@hotmail.com (S.W.); wanyi@nhu.edu.tw (W.-Y.W.); baokhanhleho@gmail.com (K.B.H.L.) \\ 2 Program of International Business, Nanhua University, Chiayi County 62249, Taiwan \\ * Correspondence: yksuper889@nhu.edu.tw; Tel.: +886-5-2721001 (ext. 56531)
}

Citation: Wang, S.; Liao, Y.-K.; Wu, W.-Y.; Le, K.B.H. The Role of Corporate Social Responsibility Perceptions in Brand Equity, Brand Credibility, Brand Reputation, and Purchase Intentions. Sustainability 2021, 13, 11975. https://doi.org/ $10.3390 /$ su132111975

Academic Editor: Andrea Pérez

Received: 13 September 2021

Accepted: 22 October 2021

Published: 29 October 2021

Publisher's Note: MDPI stays neutral with regard to jurisdictional claims in published maps and institutional affiliations.

Copyright: (c) 2021 by the authors. Licensee MDPI, Basel, Switzerland. This article is an open access article distributed under the terms and conditions of the Creative Commons Attribution (CC BY) license (https:/ / creativecommons.org/licenses/by/ $4.0 /)$.

\begin{abstract}
Corporate social responsibility (CSR) is becoming one of the most critical challenges that firms must address to survive in the competitive market. This study investigates the impact of customers' CSR perceptions on their purchase intentions as mediated by brand equity, brand credibility, and brand reputation in order to identify the benefits of CSR integration for business development. The study employs a quantitative approach to collect data from customers who purchase cosmetics through an online survey. PLS-SEM software is used to analyze the data from the 380 responses. The results indicate that customers' perceptions of the CSR of a firm affect their intention to purchase its brands in the future. Brand equity, brand credibility, and brand reputation mediate the impact of CSR perceptions on purchase intentions. Since previous studies have not employed a comprehensive approach to verifying the influence that CSR exerts through brand credibility, brand reputation, and brand equity, the results provide an essential reference for academics who conduct empirical research on the subject. This paper is also particularly beneficial for marketers and managers who wish to develop marketing strategies and brand management techniques that boost business efficiency.
\end{abstract}

Keywords: corporate social responsibility; brand equity; brand credibility; brand reputation; purchase intentions

\section{Research Background and Motivation}

At present, businesses and governments consider corporate social responsibility (CSR) to be the primary remedy for social ills [1]. The role of CSR and the contribution of companies to society is undeniably critical. However, CSR is important not only for addressing global issues but also for improving organizational performance. Companies have long been familiar with CSR, which is the most crucial standard business practice that they must employ if they want to survive in a chaotic and competitive business environment. Kim and Lee [2] contended that, from a marketing perspective, CSR can be an effective promotional strategy that enhances corporate image and customer behavior. Furthermore, the benefits of CSR extend beyond sales. CSR initiatives have a strong impact on customer and stakeholder expectations, which leads to improvements in firm performance [3-5].

Over the decades, research on CSR has adopted a wide variety of perspectives, but it has produced no comprehensive results. One explanation is that CSR concerns transactions between dissimilar companies, industries, cultures, and countries [6]. Accordingly, the present study investigates the advantages of CSR in a specific industry, namely cosmetics. The cosmetics industry is exceptionally customer-oriented. Customers' familiarity with the substances that they apply to their bodies poses challenges to brands. CSR concerns are no longer exclusive to niche players; they also affect large cosmetics companies, which 
attach labels such as "organic," sustainable," "green," and "natural" to their products, brands, and business practices. Firms must pursue sustainable progress, for instance by focusing on the environment, the ingredients that they use, human rights, cruelty [7], and greenwashing [8].

By adopting a brand management perspective, this study attributes brand equity (BE), brand reputation (BR), and brand credibility (BC), which ultimately intensify purchase intentions (PI), to CSR in the cosmetics sector. By generating value for customers, $\mathrm{BE}$ enhances information processing to enable purchasing decisions to be made confidently and with strong self-esteem. Baalbaki and Guzmán [9] suggested that CSR is an integral part of BE. CSR is considered to be a means of promoting BE by creating a positive image in the customer's mind. Buyers' perceptions of CSR activities can impact brand performance and BE [10]. Many studies have suggested that CSR can build BE [11,12]. Javed et al. [13] confirmed that CSR initiatives have a positive impact on BR. When companies involve stakeholders in social activities, they gain their approval [14]. Customers care not only about products but also about company practices $[15,16]$. BC reflects the past efforts of the firm [17]. Kim [2] suggested that CSR initiatives increase trust and lead to higher BC. Nonetheless, a more comprehensive research model for verifying the mediating influence of brand-related constructs on the effect of CSR on PI is yet to be developed.

The present study aims to fill this research gap by demonstrating how CSR affects PI through the mediation of BE, BC, and BR. Since the effects of CSR differ across industries [18], the paper focuses on cosmetics. One of the academic contributions of the study is that it emphasizes the importance of CSR perceptions for PIs by explaining how the manager of a business might improve their understanding and knowledge of the role of CSR and how they can design fruitful communication strategies. The relationship between CSR and PIs is critical to understand the limited familiarity with CSR that Vietnamese cosmetics companies exhibit, and the findings may encourage them to engage in CSR activities.

\section{Literature Review and Hypothesis Development}

\subsection{CSR Perceptions and Brand Credibility, Brand Reputation, and Brand Equity}

Customers' perceptions of CSR activities can strengthen their trust in a company by influencing appraisals of expertise and integrity. CSR affects trust in individuals who share interests and values easily [19]. Involving ethics and responsibility in strategic decisions bolsters perceptions of credibility among stakeholders. Rothenhoefer [15] investigated the connection between CSR and corporate reputation by using fuzzy-set qualitative comparative analysis (fsQCA). By investigating CSR in the hospitality sector, Martínez and Rodriguez del Bosque [20] demonstrated that CSR activities, alongside quality, star ratings, and endorsements, play a critical role in enhancing brand trust, which then affects brand loyalty. Hur, Kim, and Woo [21] further proposed that CSR has a direct positive effect on corporate BC. Corporate BC also mediates the relationship between CSR and corporate reputation. Vera-Martínez, Alvarado-Herrera, and Curras-Pérez [22] used the sustainability-centric paradigm to explain how perceived CSR affects BC. Zayyad et al. [6] confirmed the relationship between CSR and BC, they also suggested that banks that practice CSR for the benefit of their stakeholders, society, and the environment can increase their BC, which ultimately affects patronage intentions positively, including word of mouth and repurchase intentions. A negative CSR perception can lead to a reduction in BC. To build BC, firms must implement a CSR program and communicate it appropriately [23]. On the basis of these contributions, the following hypothesis was formulated:

Hypothesis 1 (H1). CSR has a positive impact on BC.

BR is the result of past actions and management. Therefore, involvement in CSR activities can be an effective means of improving reputation [11]. The relationship between CSR and BR can be explained by signaling theory [24,25]. According to Boulding and 
Kirmani [26] when buyers are faced with a vast amount of information on the market, they seek out signals that enable them to distinguish responsible sellers from irresponsible ones. CSR activities can thus function as a signal that improves company image. Many studies have observed the direct impact of CSR perceptions on BR. According to Qasim et al. [27], whose study is premised on social exchange theory, CSR supplies customers with an ethical impression of a brand, which increases BR and thus reassures the individuals who wish to purchase its products. As Pérez-Cornejo et al. [28] wrote, CSR performance, in its social, economic, and environmental aspects, significantly and positively influences the reputation of firms. This conclusion has also found support in the works of $[10,29,30]$. Zayyad et al. [6] found that stakeholder-focused CSR activities increase customer trust and decrease uncertainty about a firm, resulting in stronger patronage intentions. Lin, Tsai, Chiu, and Liu [31] argued that dramatic discrepancies between the CSR-related statements of a firm and its actual business practices exert a significantly negative effect on consumer trust and PI. Accordingly, the following hypothesis was formulated:

Hypothesis 2 (H2). CSR has a positive impact on BR.

Several studies have proven the impact of CSR on BE. According to Singh and Verma [12], CSR strategies can improve BE and ultimately help a firm to obtain competitive advantages. Hur et al. [11] also found that CSR perceptions influence BE and BC directly, whereas BR acts as a partial mediator of the relationship between CSR and BE. Martínez and Nishiyama [32] claimed that CSR can enable hotels to secure competitive advantages by increasing brand loyalty, improving brand image and brand awareness, and by changing quality perceptions. BE is formed through contact with multiple stakeholders. Therefore, the better a firm's knowledge of the means of satisfying stakeholder expectations, the higher its BE.

Brand association is an emotional feature that is linked to the psychological dimension of feelings and attitudes toward a company, which tend to vary [33]. CSR programs enhance brand associations because CSR improves the image of a firm, causing it to appear more honest, ethical, or sustainable [34,35]. Both CSR and perceived quality focus on generating perceptions of reliability, sincerity, and mutual benefit [36]. Customers' support of the social activities of firms manifests in positive perceptions and attitudes towards products, especially perceptions and attitudes that pertain to quality [37]. Therefore, CSR strategies can improve customers' overall assessment of products and services and thus quality perceptions. Once customers perceive high quality, they treat the company as being reliable and honest [38]. Likewise, customers assume that reliable and trustworthy brands offer high-quality products [36]. Perceptions of CSR activities can also influence brand awareness [39] by increasing the likelihood that customers will recognize a brand. However, low awareness of CSR activities can hinder BE and communication. Finally, the direct correlation between CSR perceptions and brand loyalty has been proven in many studies e.g., [40,41]. The socially responsible activities of firms are positive aspects of brand association. They influence customer loyalty and its manifestations in attitudes and behaviors directly [40]. Socially responsible activities demonstrate respect and care for customers and the community. Therefore, the following hypothesis is proposed:

Hypothesis 3 (H3). CSR has a positive impact on BE.

\subsection{Brand Credibility, Brand Equity, Brand Reputation, and Purchase Intention}

$\mathrm{BC}$ is a critical antecedent of BE [42]. According to signaling theory, BC can contribute to $\mathrm{BE}$ by improving perceptions of brand quality and utility [43]. Erdem and Swait [44] defined BC as the ability of a brand to keep its promises continuously and wrote that it is created by combining reliability and expertise. Vishwanathan et al. [16] examined the concept of strategic CSR by developing a meta-analysis of the empirical evidence on the relationship between CSR and corporate financial performance. If a brand fails to 
fulfill its promises, its BE would be affected negatively. Spry, Pappu, and Cornwell [43] argued that $\mathrm{BC}$ promotes consumer-based BE. Mathew, Ali, and Thomas [45] contended that $B C$, defined as expertise and trustworthiness, has a significant effect on BE. They argued that credible brands enjoy lower information-processing costs and lower perceived risk, which may result in stronger brand recall, brand association, and consumer-based BE. Rifi and Mostafa [46] stated that satisfaction with service recovery improves BC, which enhances customer-based BE further. Algammash [47] took the view that BC affects brand commitment, which, in turn, exerts an influence on BE. Marin, Ruiz, and Rubio [34] wrote that CSR initiatives are linked strongly to positive company evaluations and consumer loyalty. According to Chinomona [48], BC assures customers when they feel vulnerable. A trustworthy brand that keeps its promises generates loyalty. Thus, Marin et al., [34] argued that CSR initiatives are linked to stronger loyalty both because the consumer's evaluation of the company becomes more positive and because they identify with the company more strongly. Therefore, the following hypothesis is proposed:

Hypothesis 4 (H4). BC has a positive impact on $B E$.

BC concerns the believability of a brand's promises [49]. Credibility is derived from the efforts of a company and the perceptions of its stakeholders, especially its customers. $\mathrm{BC}$ thus reflects both messages and actions. Many researchers have concluded that BC influences BR positively [2,11,50]. Isaksson, Kiessling, and Havvey [51] thus wrote that CSR can generate reputational value for firms. When a brand delivers on its promises, such as those that pertain to quality, its reputation improves. However, credibility is as fragile as a reputation-once lost, it is difficult to recover. As Song et al. [52] suggested that, by fulfilling its promises, a company can obtain a favorable reputation. At the same time, failure to keep promises poses reputational risks.

Pineiro-Chousa, Vizcaino-Gonzalez, and Lopez-Cabarcos [53] developed a novel approach to reputation management. Reputation may be perceived as a source of risk, as a competitive advantage, and as reputational intelligence. All of these conceptualizations are connected to CSR. Entrepreneurs can start by protecting their companies from reputational threats. Then, they can acquire reputational opportunities and develop reputational intelligence. Sontaite-Petkevicience [54] argued that CSR can be used to enhance corporate reputation. Bianchi, Bruno, and Sarabia-Sanchez [55] wrote that CSR can impact PI in the short run and BR in the long run. LaMastra [56] proposed using CSR strategies to repair reputations. Rothenhoefer [15] and Vishwanath [16] also pointed out that CSR has a positive effect on corporate reputation. Credibility enhances perceptions of the quality of products and services because varying credibility levels can affect psychological assessments. Ultimately, consumers tend to conclude that companies that adhere to their promises about quality are of good repute [11]. The following hypothesis emerges:

\section{Hypothesis 5 (H5). BC has a positive impact on $B R$.}

Customers who believe that companies are willing and able to act on their promises are more likely to purchase their products and services [57]. Signaling theory suggests that BC can increase the probability of purchase [44]. Jeng [57], drawing on signaling theory and relationship marketing theory, posited that BC augments PI by increasing decision convenience and by enhancing affective commitment. Wang and Yang [58] also found that $\mathrm{BC}$ is one of the most influential factors that affect PI. Afzali and Kim [59] argued that CSR activities can elicit positive responses such as trust, support, and authenticity, which further improve corporate evaluations, product associations, and PI. In this sense, BC is a signal because it is formed from the accumulated results of past marketing strategies and because it serves as a source of knowledge and experience. Customers consider BC to be a credible source of knowledge and information about products and an antecedent of their confidence in product claims. Therefore, BC decreases expected costs and the costs of gathering, processing, and disambiguating information while increasing perceived 
value [60]. By helping customers to lighten the cognitive load of product choice, $B C$ increases the likelihood of purchase: when customers believe that a brand is willing and able to be trustworthy and reliable, they are more likely to purchase products [61] Accordingly, the following hypothesis is formulated:

Hypothesis 6 (H6). BC has a positive impact on PI.

\subsection{Brand Equity, Brand Reputation, and Purchase Intention}

The relationship between BE and BR has been examined in many studies e.g., [62,63]. Brand associations concern the immediate mental impressions that appear in the minds of customers, whereas BR is the customers' evaluation of a brand. In psychological terms, what customers see, hear, and experience affects their thoughts and judgments. Marketers adjust brand associations with the aim of supporting BR. A positive image affects the feelings and assessments that customers ascribe to a company, thus enhancing its reputation [64]. Brand awareness refers to the possibility of a brand appearing in the consciousness of a customer, which is liable to reduce their consumption of alternative products. Mathew et al. [45] explained that brand awareness can enhance BR by affecting BC, which leads to long-term development $[65,66]$. Furthermore, BR is the result of the past actions of the company, which send signals to customers. Service quality affects reputation. Consequently, companies attempt to improve quality perceptions and, in this way, their reputations [67]. When customers accumulate positive experiences of product performance, they develop positive attitudes and feelings towards the brand. Many have explored the role of $\mathrm{BE}$ as an antecedent of $\mathrm{BR}$ e.g., [68,69]. Others have attempted to prove the reverse relationship [70]. The present study explores the impact of BE on BR. Accordingly, the following hypothesis is proposed:

Hypothesis 7 (H7). BE has a positive impact on BR.

The existence of a direct link between BE and PI has been demonstrated in numerous studies (e.g., [71,72]). Aaker [73] suggested that BE is stored in the minds of customers and retrieved when a product is purchased. The higher the $\mathrm{BE}$, the more the customers want to consume the product or service, and their PI is strongly affected. Keller [74] suggested three mechanisms through which brand awareness affects purchase decisions: First, when customers hear about or see brand attributes, they think of the brand immediately. Second, once aware of a brand, customers have the tendency to consider it and to eliminate its rivals from their decision-making processes [75]. Finally, brand awareness influences purchase decisions through the formation of brand associations [74]. Brand awareness allows customers to distinguish a brand from others and to include it in their consideration set, which leads to favorable attitudes and purchasing behaviors [76,77]. Perceived quality plays a vital role in aiding customers in their choice of products and services [76]. It is a commonly held belief, especially in environments where fake or low-quality products abound, that the strength of quality perceptions causes customers to favor the products of one brand over those of another [78]. Brand association denotes the accumulated information about a brand. It is stored in the minds of customers, and it can be recalled readily during the purchase process [79]. Moreover, brand associations are relative to target customers, typical utility, and reliability. In this way, they cause customers to make purchases [77]. Brand loyalty refers to one's commitment to brands, including the commitment to purchase products and services consistently [73]. Loyalty reduces the time that customers need to assess the quality (or any other attribute) of a brand and makes it more likely that they will choose that brand [80]. The following hypothesis emerges:

Hypothesis $\mathbf{8}$ (H8). BE has a positive impact on PI. 


\subsection{Brand Reputation and Purchase Intentions}

BR has been shown to exert a positive effect on stakeholder outcomes and behavioral intentions, including customer PI, through the perceptions and attitudes of customers. Maden et al. [81] stated that a positive reputation causes customers to perceive particular purchase transactions as being more beneficial than others, saving costs on information searching among an ambiguity and asymmetry of information. In addition, customers tend to link positive reputation with high quality, so they feel satisfied with their purchases. Writing on hospitality, Agmeka et al. [82] suggested that the use of a reputable brand induces pride in customers. For this reason, they form intentions to purchase reputable brands. Qasim, Siam, and Sallaeh [27] wrote that CSR affects BR, which improves PI. Moreover, according to signaling theory, BR transmits information about the intrinsic and intangible characteristics of products, such as quality, particularly when there is no other means of evaluating them. Thus, BR can affect behavioral intentions directly [67]. Negative BR can result in negative PI because customers tend to focus on anticipated losses rather than on anticipated gains and thus overvalue the importance of negative information [83]. Therefore, the following hypothesis ought to be explored:

Hypothesis 9 (H9). BR has a positive impact on PI.

\section{Research Methodology}

\subsection{Research Model}

This research framework that animates this study is based on the development of the research hypotheses (Figure 1). The study integrates the resource-based view [84-86], signaling theory [24], stakeholder theory $[4,87]$, and BE theory $[73,88]$ to examine the relationship between CSR perceptions and PI through BE.

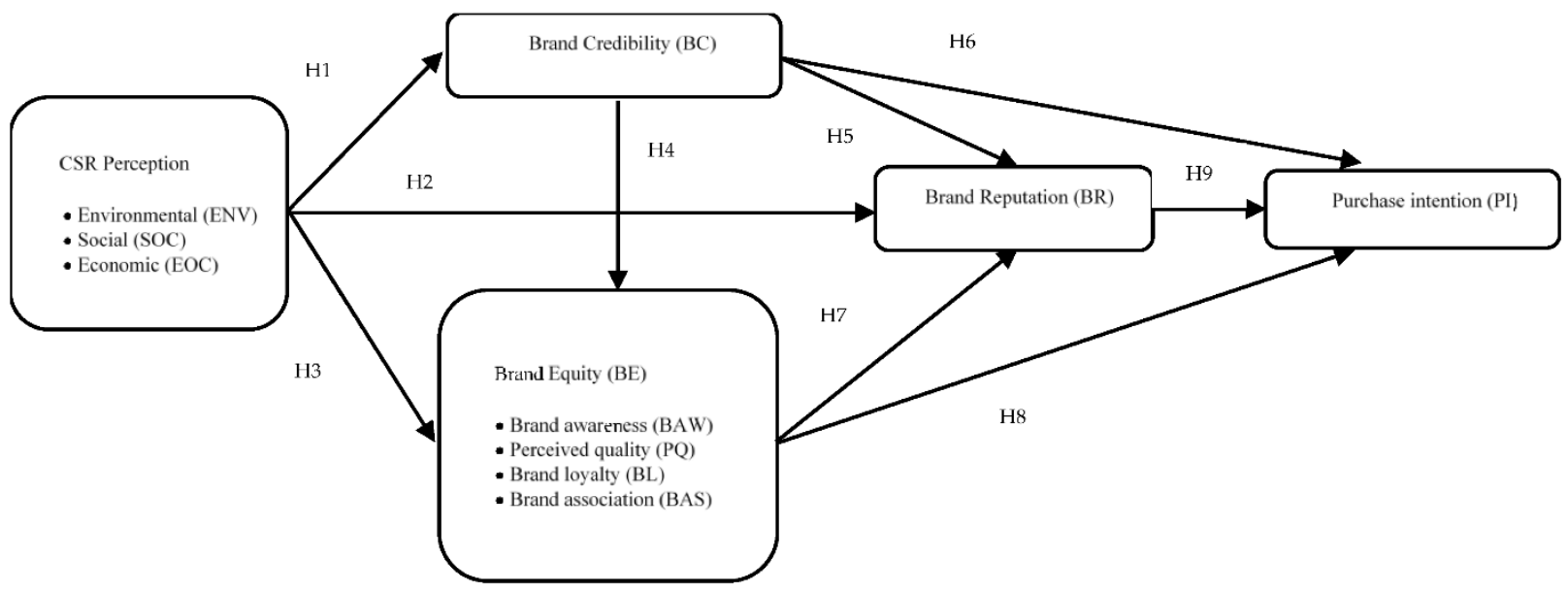

Figure 1. Research Framework.

\subsection{Research Design}

A questionnaire was distributed to Vietnamese respondents through e-mail and social media (e.g., Facebook, Zalo, and Line). The respondents had made purchases and were aware of social issues. Non-random convenience sampling was employed. The target sample size was calculated by using the formula developed by Marcoulides and Saunders [89] and Kerlinger and Lee [90], which is as follows:

$$
n=\frac{Z_{\frac{\alpha}{2}}^{2} \cdot \sigma^{2}}{e^{2}},
$$

where $Z$ is the standard score, $\sigma$ is standard deviation, and $e$ is tolerance of ambiloquy. 
A seven-point Likert scale was used in the questionnaire, and sampling was assessed as follows:

$$
n=\frac{Z_{\frac{\alpha}{2}} \cdot \sigma^{2}}{e^{2}}=\frac{Z_{\frac{\alpha}{2}} \cdot \alpha^{2}}{7 x^{2}}
$$

assuming that $e=2 \%, Z=1.96$, and $\sigma=1.3$.

Thus, the estimated number of samples was calculated as follows:

$$
n=\frac{1.96^{2} \times 1.3^{2}}{(7 \times 0.02)^{2}}=331 .
$$

To meet these criteria, the target sample size was set at 380 .

\subsection{Research Instrument and Measurement}

The questionnaire items, their factor loadings, and Cronbach's alpha are presented in the Appendix A. The questionnaire included five constructs: (1) CSR perceptions, (2) BE, (3) BC, (4) BR, and (5) PI. The questionnaire consisted of six sections with 56 questions in total, among which were eight questions that solicited personal data and data about cosmetic purchases. The remaining questions required the participants to express their opinions about CSR, BE, BC, BR, and PI for the cosmetics brand of their choice. All questionnaire items were measured through a seven-point Likert ( 1 = "totally disagree"; $7=$ "totally agree"). The data were collected over a period of six months, from July 2020 to January 2021, in Vietnam.

\subsection{Questionnaire Translation}

To adapt the questionnaire to Vietnamese respondents, it was translated from English to Vietnamese. The back-translation method was applied. Back translation, first introduced by Brislin [91], is used to evaluate and control the quality of questionnaire translations in cross-cultural research and international marketing. Initially, two language experts from a translation agency were retained to conduct a forward translation. Then, a back translation was prepared independently by two other experts. Finally, one translator compared the back-translated version to the original and discussed the differences with the authors. The translation process lasted for two weeks, yielding the final version of the questionnaire.

\section{Results and Discussion}

\subsection{Respondent Characteristics}

As can be seen from Table 1,57.6\% of the those who provided valid responses were female. Among the respondents, $45 \%$ were aged between 15 and 25, and 25\% were aged between 26 and 35. Most respondents $(96.8 \%)$ had obtained a bachelor's degree or higher, and $57.1 \%$ had an average income of less than 10 million Vietnamese dong. The average frequency of cosmetics purchases was moderate, with $28.4 \%$ making a purchase once every three months, $28.2 \%$ making a purchase once a year, and $25.8 \%$ making a purchase once every six months. 
Table 1. Characteristics of the Respondents.

\begin{tabular}{|c|c|c|c|}
\hline \multicolumn{2}{|c|}{ Descriptive Variable } & \multirow{2}{*}{$\begin{array}{c}\begin{array}{c}\text { Frequency } \\
(\mathbf{N}=\mathbf{3 8 0})\end{array} \\
219\end{array}$} & \multirow{2}{*}{$\begin{array}{c}\begin{array}{c}\text { Percentage } \\
(\%)\end{array} \\
57.6\end{array}$} \\
\hline & Female & & \\
\hline Gender & Male & 161 & 42.4 \\
\hline \multirow{4}{*}{ Age } & Under 15 & 2 & 0.5 \\
\hline & $15-25$ & 171 & 45 \\
\hline & $26-35$ & 95 & 25 \\
\hline & Over 35 & 112 & 29.5 \\
\hline \multirow{4}{*}{ Education } & High school diploma & 12 & 3.1 \\
\hline & Bachelor's degree or equivalent & 267 & 70.3 \\
\hline & Master's degree or equivalent & 90 & 23.7 \\
\hline & $\mathrm{PhD}$ or equivalent & 11 & 2.9 \\
\hline \multirow{3}{*}{ Monthly income } & Less than 10 million dong & 217 & 57.1 \\
\hline & 10-20 million dong & 108 & 28.4 \\
\hline & More than 20 million dong & 55 & 14.5 \\
\hline \multirow{6}{*}{$\begin{array}{l}\text { Frequency of buying } \\
\text { cosmetic products }\end{array}$} & Once a year & 107 & 28.2 \\
\hline & Every 3 months & 108 & 28.4 \\
\hline & Every 6 months & 98 & 25.8 \\
\hline & Once a month & 47 & 12.4 \\
\hline & More than once a month & 20 & 5.2 \\
\hline & Total & 380 & 100 \\
\hline
\end{tabular}

\subsection{Evaluation of the Measurement Model}

Partial least squares structural equation modeling (PLS-SEM) was used to evaluate the measurement model and to ensure reliability, convergent validity, and discriminant validity. Tables 2 and 3 present the results of the assessment of the measurement model.

Table 2. Assessment of Reliability and Convergent Validity.

\begin{tabular}{ccccc}
\hline Variable & AVE & CR & Cronbach's Alpha & $\boldsymbol{R}^{\mathbf{2}}$ \\
\hline CSR & 0.534 & 0.937 & 0.927 & \\
\hline BE & 0.615 & 0.971 & 0.969 & 0.390 \\
\hline BC & 0.697 & 0.902 & 0.855 & 0.418 \\
\hline BR & 0.678 & 0.894 & 0.842 & 0.639 \\
\hline PI & 0.763 & 0.906 & 0.839 & 0.613 \\
\hline
\end{tabular}

According to Table 2, the Cronbach's alpha coefficients range between 0.839 and 0.969 , and all composite reliability (CR) values exceed 0.894 . That value is above the threshold of 0.7 , which is indicative of reliability. The average variance extracted (AVE) of the constructs ranges between 0.534 and 0.763 , in excess of the 0.5 threshold, indicating construct convergence. The square root of the AVE, which is presented in Table 3, is higher than that of its strongest correlation to any test construct, in line with Fornell and Larcker [92]. Table 3 also shows that all of the heterotrait-monotrait (HTMT) values are below 0.85 . Given that these criteria are satisfied, the discriminant validity of the research constructs is established.

\subsubsection{Assessment of $R^{2}$ Value}

The (adjusted) $R^{2}$ values of four endogenous latent variables, namely $\mathrm{BC}, \mathrm{BE}, \mathrm{BR}$, and PI, were calculated. CSR perception was found to explain $38.9 \%$ of the variance in BC. Furthermore, $41.5 \%$ of the variance in $\mathrm{BE}$ can be explained by the exogenous variables. Finally, $63.9 \%$ and $61.3 \%$ of BR and PI, respectively, are explained by the corresponding independent variables. 
Table 3. Discriminant Validity Results (Fornell-Larcker and HTMT Criteria).

\begin{tabular}{cccccc}
\hline \multicolumn{5}{c}{ Fornell-Larcker Criterion } \\
\hline BC & BE & BR & CSR & PI \\
\hline BE & 0.835 & & & & \\
\hline BR & 0.498 & 0.785 & & \\
\hline CSR & 0.677 & 0.650 & 0.824 & 0.731 & \\
\hline PI & 0.630 & 0.625 & 0.678 & 0.705 & \\
\hline BC & & HTMT criterion & & \\
\hline BE & 0.546 & & & & \\
\hline BR & 0.796 & 0.720 & & \\
\hline CSR & 0.701 & 0.657 & 0.7968 & \\
\hline PI & 0.743 & 0.752 & 0.834 & \\
\hline
\end{tabular}

\subsubsection{Assessment of Effect Size $f^{2}$}

Since the analysis of the path coefficient did not generate information about effect size or the extent to which the exogenous variables influence the endogenous variables in the constructs, an $f^{2}$ value evaluation was conducted. Table 4 displays the results. According to Cohen [93] and Hair et al. [94], effect size is considered small, medium, or large if $f^{2}$ is higher than $0.02,0.15$, or 0.35 , respectively. If $f^{2}$ is below 0.02 , no effect exists as between the independent and the dependent variables. CSR has a large effect on BC $\left(f^{2}=0.640\right)$. The size of the effects in the relationships between CSR and BE $\left(f^{2}=0.287\right), \mathrm{BC}$ and BR $\left(f^{2}=0.185\right)$, and BE and PI $\left(f^{2}\right.$ value $\left.=0.183\right)$ is medium. The effects of CSR on BR $\left(f^{2}=0.126\right)$, BR on PI $\left(f^{2}=0.081\right), \mathrm{BE}$ on BR $\left(f^{2}=0.139\right), \mathrm{BC}$ on BE $\left(f^{2}=0.032\right)$, and BC on PI $\left(f^{2}=0.081\right)$ are small.

Table 4. Multicollinearity Test.

\begin{tabular}{ccccc}
\hline & BC & BE & BR & PI \\
\hline BC & & 1.640 & 1.692 & 2.005 \\
\hline BE & & 1.718 & 1.958 \\
\hline BR & & & 2.770 \\
\hline CSR & 1.000 & 1.640 & 2.111 & 2.376 \\
\hline
\end{tabular}

\subsection{Evaluation of the Structural Model}

The structural model was assessed using the parameter estimations of the paths between the research constructs. To evaluate the significance of every path coefficient and to test the hypotheses, the sample of 380 respondents was subjected to a nonparametric bootstrapping procedure with a subsample of 5000 .

\subsubsection{Multicollinearity Test}

Multicollinearity occurs when a strong correlation obtains between two or more constructs. Multicollinearity inflates standard errors, making assessments of the influence of independent variables and comparisons between them unreliable [95]. According to Table 4, all variance inflation factor values are lower than 5.0. Therefore, there are no obvious multicollinearity concerns. 


\subsubsection{Direct and Indirect Effects}

The bootstrapping resampling technique was employed to evaluate the relationship between the constructs in the model. Hair et al. [96] recommended 5000 bootstrapping subsamples. Table 5 presents the path coefficients for the testing of the hypotheses. The results indicate that CSR affects BE, BC, and BR. Therefore, $\mathrm{H1}, \mathrm{H} 2$, and $\mathrm{H} 3$ are supported. $\mathrm{BC}$ affected $\mathrm{BE}, \mathrm{BR}$, and $\mathrm{BE}$. It follows that $\mathrm{H} 5$ and $\mathrm{H} 6$ are supported. Additionally, PI was proven to be affected by BC, BR, and BE. Therefore, $\mathrm{H} 7, \mathrm{H} 8$, and $\mathrm{H} 9$ are also supported.

Table 5. Results: Direct Effects.

\begin{tabular}{ccccccc}
\hline Hypothesis & Path & $f^{2}$ & $\begin{array}{c}\text { Standardized } \\
\text { Estimate }\end{array}$ & $\boldsymbol{t}$ & $\boldsymbol{p}$ & Remarks \\
\hline $\mathrm{H} 1$ & $\mathrm{CSR} \rightarrow \mathrm{BC}$ & 0.640 & 0.625 & 13.095 & 0.001 & Supported \\
\hline $\mathrm{H} 2$ & $\mathrm{CSR} \rightarrow \mathrm{BR}$ & 0.126 & 0.309 & 5.627 & 0.001 & Supported \\
\hline $\mathrm{H} 3$ & $\mathrm{CSR} \rightarrow \mathrm{BE}$ & 0.287 & 0.526 & 10.628 & 0.001 & Supported \\
\hline $\mathrm{H} 4$ & $\mathrm{BC} \rightarrow \mathrm{BE}$ & 0.032 & 0.173 & 3.528 & 0.001 & Supported \\
\hline $\mathrm{H} 5$ & $\mathrm{BC} \rightarrow \mathrm{BR}$ & 0.185 & 0.337 & 8.150 & 0.001 & Supported \\
\hline $\mathrm{H} 6$ & $\mathrm{BE} \rightarrow \mathrm{BR}$ & 0.139 & 0.293 & 6.735 & 0.001 & Supported \\
\hline $\mathrm{H} 7$ & $\mathrm{BC} \rightarrow \mathrm{PI}$ & 0.081 & 0.262 & 6.189 & 0.001 & Supported \\
\hline $\mathrm{H} 8$ & $\mathrm{BE} \rightarrow \mathrm{PI}$ & 0.183 & 0.358 & 7.925 & 0.001 & Supported \\
\hline $\mathrm{H} 9$ & $\mathrm{BR} \rightarrow \mathrm{PI}$ & 0.081 & 0.314 & 6.013 & 0.001 & Supported \\
\hline
\end{tabular}

Bootstrapping Smart PLS was used to test the hypotheses about the mediating role of BC, BE, and BR. According to Zhao et al. [97], the direct effect of the independent variable on the mediator $\left(p_{1}\right)$, the effect of the mediator on the dependent variable $\left(p_{2}\right)$, and the effect of the independent variable on the dependent variable $\left(p_{3}\right)$ must be tested to analyze the role of mediators. Zhao et al. [97] and Hair [96] suggested that, if $p_{1}, p_{2}$, and $p_{3}$ all are insignificant, then no mediation effect may be said to be obtained. If $p_{1}$ and $p_{2}$ are significant while $p_{3}$ is insignificant, there is a full mediation. If $p_{1}, p_{2}$, and $p_{3}$ are all significant, there is full mediation. The use of Smart PLS 3.0, the PLS-SEM algorithm, and the bootstrapping procedure enabled the identification of direct and total indirect effects in the mediation analysis [96]. The results that are presented in Table 6 indicate that $\mathrm{BC}$ mediates the relationship between CSR perceptions and PI, and that BE mediates the influence of CSR perceptions on PI. However, BC only partially mediates the relationship between CSR perceptions and BR. 
Table 6. Results of Mediation Testing.

\begin{tabular}{ccccc}
\hline Direct and Indirect Path & Standardized Estimate & $t$ & $p$ & Remarks \\
\hline $\mathrm{CSR} \rightarrow$ PI & -0.011 & 0.285 & 0.776 & Insignificant \\
\hline $\mathrm{CSR} \rightarrow \mathrm{BC}$ & 0.625 & 12.962 & 0.000 & Significant \\
\hline $\mathrm{BC} \rightarrow$ PI & 0.251 & 5.768 & 0.000 & Significant \\
\hline $\mathrm{CSR} \rightarrow \mathrm{BC} \rightarrow$ PI & 0.164 & 5.432 & 0.000 & Significant \\
\hline $\mathrm{CSR} \rightarrow$ PI & -0.011 & 0.285 & 0.776 & Insignificant \\
\hline $\mathrm{CSR} \rightarrow \mathrm{BE}$ & 0.524 & 11.254 & 0.000 & Significant \\
\hline $\mathrm{BE} \rightarrow$ PI & 0.372 & 7.996 & 0.000 & Significant \\
\hline $\mathrm{CSR} \rightarrow \mathrm{BE} \rightarrow$ PI & 0.188 & 5.964 & 0.000 & Significant \\
\hline $\mathrm{CSR} \rightarrow$ PI & -0.011 & 0.285 & 0.776 & Insignificant \\
\hline $\mathrm{CSR} \rightarrow \mathrm{BR}$ & 0.309 & 5.695 & 0.000 & Significant \\
\hline $\mathrm{BR} \rightarrow$ PI & 0.295 & 4.971 & 0.000 & Significant \\
\hline $\mathrm{CSR} \rightarrow \mathrm{BR} \rightarrow$ PI & 0.097 & 3.803 & 0.000 & Significant \\
\hline $\mathrm{CSR} \rightarrow \mathrm{BR}$ & 0.309 & 5.695 & 0.000 & Significant \\
\hline $\mathrm{CSR} \rightarrow \mathrm{BC}$ & 0.625 & 12.962 & 0.000 & Significant \\
\hline $\mathrm{BC} \rightarrow \mathrm{BR}$ & 0.336 & 8.121 & 0.000 & Significant \\
\hline $\mathrm{CSR} \rightarrow \mathrm{BC} \rightarrow \mathrm{BR}$ & 0.210 & 3.239 & 0.000 & Significant \\
\hline $\mathrm{CSR} \rightarrow \mathrm{BR}$ & 0.309 & 5.695 & 0.000 & Significant \\
\hline $\mathrm{CSR} \rightarrow \mathrm{BE}$ & 0.524 & 11.254 & 0.000 & Significant \\
\hline $\mathrm{BE} \rightarrow \mathrm{BR}$ & 0.294 & 6.663 & 0.000 & Significant \\
\hline $\mathrm{CSR} \rightarrow \mathrm{BE} \rightarrow \mathrm{BR}$ & 0.154 & 5.647 & 0.000 & Significant \\
\hline
\end{tabular}

\section{Conclusions and Suggestions}

\subsection{Research Conclusion}

This paper is premised on an integrative model of CSR perceptions, brand management, and PI. The results of the theoretical examination and the data analysis yielded several conclusions.

First, CSR perceptions have a direct impact on BC, BE, and BR. CSR not only builds the credibility of a company [98] but also facilitates the formation of close trust-based relationships with customers [20]. In the modern world, customers are increasingly aware of global issues and pursue sustainable lives. For this reason, it is easier for companies to gain their trust through CSR initiatives [19]. The relationship between CSR and BC has been established in many studies (e.g., [6]). Furthermore, CSR improves the BE of companies [12] by affecting perceived quality, brand association, brand awareness, and brand loyalty. By becoming involved in CSR programs, companies project honesty, ethical commitment, and sustainability [35]. A positive impression can therefore improve attitudes toward the products of a company [36]. Positive impressions also make it easier for customers to recognize brands [39], and they can lead to customer loyalty, which manifests in both attitudes and behaviors [40]. In this paper, it was proven that CSR perceptions have a direct impact on BR, which is in line with several previous studies, such as those by $[10,15,16]$.

Second, BC, BE, and BR affect PI directly. Purchasing behaviors are considered when customers have already formed a belief that a company has fulfilled all of its promises $[57,61]$. BE is stored in customers' minds and retrieved when they buy products, enabling them to distinguish between the products of different brands [75-77]. Maden et al. [81] argued that customers form the intention to choose brands with positive reputations because doing so reduces the time and expense that must otherwise be expended to discover and experiment with other unfamiliar brands. 
Third, the relationships between $\mathrm{BC}, \mathrm{BE}$, and $\mathrm{BR}$ were confirmed. These relationships have also been investigated extensively in the past [21,48,63,64]. Song et al. [52] showed that a company can improve its reputation by increasing its credibility. Conversely, failing to maintain credibility leads to deteriorations in reputation. In addition, accumulating $\mathrm{BE}$ can be futile if $\mathrm{BC}$ is compromised [48]. Foroudi et al. [64] advocated manipulating brand associations to support BR. BR increases when customers hold a positive image of a brand in their minds, when they recognize its superiority, and when they have positive experiences with its products $[66,68]$.

Finally, BC, BE, and BR serve as powerful mediators. BC mediates the relationship between CSR perceptions and PI fully. As Zayyad et al. [6] pointed out, when CSR initiatives and messages are communicated properly, customers believe the promises of the company and consider purchasing its products. $\mathrm{BC}$ also mediates the relationship between CSR perceptions and BR partially. When customers observe CSR activities, they are far more likely to believe that the company is reliable and trustworthy [11], which improves the reputation of its brand [50]. As far as BE is concerned, it was found that it acts as a powerful mediator that influences the path from CSR perceptions to PI directly and the path from CSR perceptions to BR partially. CSR can contribute to the formation of an ethical, sustainable, and reliable image, therefore improving perceived brand loyalty [34]. Moreover, communicating CSR activities well can raise customer awareness. When a company succeeds in building a sustainable BE, it can maintain a positive reputation [63] and encourage customers to purchase its products [41].

\subsection{Academic Implications}

The findings of the study have several academic implications. First, by filling the gap in the literature, the present paper provides an integrative model of CSR perceptions, $\mathrm{BE}, \mathrm{BC}, \mathrm{BR}$, and PI. It integrated numerous theories. The resource-based view [84] was used to explain why CSR must be planned: it as a critical element of corporate strategies that purport to increase competitiveness. Moreover, the analysis of customer PIs that was presented here is premised on stakeholder theory [87], which also explains the purpose of CSR in corporate strategy [4]. Signaling theory was used [24] to clarify the relationships between $\mathrm{BE}, \mathrm{BC}$, and $\mathrm{BR}$. The $\mathrm{BE}$ model [73] was introduced to explain the relationship between $\mathrm{BE}$ and other factors that support the customer-based BE model [74]. While most studies of CSR rely on the CSR pyramid model by Carroll [99] to align research purposes to objects, in this paper, the triple bottom line was employed to explain CSR perceptions. Both frameworks were originally designed to describe and measure the responsibility of businesses. Carroll's [99] pyramid is the best-known model of CSR, and the triple-bottomline framework is now used widely in reports and in the strategies of governments and nongovernmental organizations. However, in this paper, it was necessary to ensure that measurement items could be understood by customers. The use of the triple-bottom-line model ensured the generality of CSR perception.

Second, even though customers' perceptions of CSR in the cosmetics market are growing in importance, there are few studies on this topic. The number of articles on CSR and its implications in various industries is increasing by the year [3]. This author believes that CSR practices are context-specific $[100,101]$ and shaped by industry conditions [51]. The most studied areas are retail, pharmaceuticals, mining and quarrying, tourism and hospitality, textile and clothing, food, banking, and finance and insurance [102]. By comparison, the cosmetics industry remains under-researched. Future research can extend the scope of the research by using countries or regions as categorizing variables.

\subsection{Managerial Implications}

The findings have several academic implications. First, business managers should be aware of the importance of CSR in their business plans as well as being familiar with the optimal means of executing CSR initiatives, especially in the cosmetics industry. The results indicate that customers are increasingly aware of CSR. For instance, they are concerned 
about animal testing, labor rights, environment-friendly ingredients, and production processes. Moreover, CSR can increase BC, BE, and BR directly as well as increasing PI indirectly. Therefore, brand managers must consider deploying CSR as a marketing tool. One trend that typifies the contemporary cosmetics industry is the preference for crueltyfree products and natural organic ingredients. CSR manifests in many other practices, such as recycled packaging, community outreach, fair trade, water projects, and civil rights advocacy. Globally, the cosmetics industry is witnessing the success of socially minded brands such as Lush and The Body Shop and the failure of MAC Cosmetics and other brands in the Chinese market because of their lack of CSR. By communicating CSR activities effectively, companies can create positive $\mathrm{BE}$ and gain the trust of customers, which enhances their reputation. In particular, companies can target socially conscious customers who share the same ethical values. They can also exploit CSR as a technique for improving business performance.

Second, BE, BC, and BR affect PI and corporate performance directly. Therefore, brand managers should design marketing strategies that focus on improving $\mathrm{BE}, \mathrm{BC}$, and $\mathrm{BR}$. To build $\mathrm{BE}$, a brand must enhance brand awareness, brand associations, perceived quality, and brand loyalty. BC should be prioritized because it can influence BR and BE directly and simultaneously. CSR can be used to show customers that the company keeps its promises. The results demonstrate that CSR can enhance BC by impressing the image of a socially responsible company onto the minds of customers.

Third, awareness of CSR among firms is increasing. Business managers should consider market development or expansion, especially in Vietnam. The present study showed that conditions in the Vietnamese market can enable socially responsible cosmetics conglomerates and local companies to flourish. The Vietnamese are becoming increasingly familiar with sustainable development. Millennials can be targeted because they are acutely aware of the importance of environmental issues. They are circumspect about the chemicals that they apply to their bodies and of the sustainability of the products that they consume.

\subsection{Limitations and Further Research}

This study verified the existence of a relationship between CSR perceptions, BC, BE, $\mathrm{BR}$, and PI theoretically and empirically. However, it has several limitations, which can provide directions for future research. First, a comprehensive model of the consequences and mediators of CSR perceptions was developed, but several variables were omitted. Further research should seek to identify other factors that affect the success or failure of brands. Second, many theories and variables were introduced to explain the paths between the variables. However, the theories and models in question were not compared. It is hoped that future researchers will undertake that task. The formation of CSR perceptions, BE, and $\mathrm{BC}$ is complicated and tends to be driven by psychological processes. Therefore, qualitative and longitudinal investigations are likely to produce more comprehensive findings. Fourth, CSR varies across industries and brands. Future researchers are encouraged to focus on specific brands to observe the execution of CSR in practice thoroughly. Finally, some might find the hypotheses of this paper dissatisfactory. Future studies could re-examine them.

Author Contributions: Conceptualization: Y.-K.L., S.W. and K.B.H.L.; Methodology: W.-Y.W. and K.B.H.L.; Investigation: K.B.H.L. and W.-Y.W.; Software: Y.-K.L. and S.W.; Formal analysis: K.B.H.L. and Y.-K.L.; Validation: Y.-K.L. and S.W.; Resources: S.W. and Y.-K.L.; Writing-original draft: S.W., Y.-K.L. and K.B.H.L.; Writing-review \& editing: W.-Y.W., Y.-K.L., and S.W.; Supervision: Y.-K.L. and W.-Y.W. All authors have read and agreed to the published version of the manuscript.

Funding: This research received no external funding.

Institutional Review Board Statement: Not applicable.

Informed Consent Statement: Not applicable.

Data Availability Statement: Not applicable.

Conflicts of Interest: The authors declare no conflict of interest. 


\section{Appendix A}

Table A1. Questionnaire Items and Research Constructs.

\begin{tabular}{|c|c|c|c|}
\hline $\begin{array}{l}\text { Research Constructs } \\
\text { and Items }\end{array}$ & Mean & SD & Adopted from \\
\hline \multicolumn{3}{|c|}{ Social Dimension (SOC) } & \multirow{17}{*}{$\begin{array}{c}\text { Fatma et al. [103]; } \\
\text { Park et al. [104]; Park [30] }\end{array}$} \\
\hline [SOC1] & 5.66 & 1.186 & \\
\hline [SOC2] & 5.61 & 1.123 & \\
\hline [SOC3] & 5.61 & 1.210 & \\
\hline [SOC4] & 5.68 & 1.202 & \\
\hline [SOC5] & 5.76 & 1.169 & \\
\hline \multicolumn{3}{|c|}{ Economic Dimension (ECO) } & \\
\hline [ECO1] & 5.96 & 1.051 & \\
\hline [ECO2] & 5.98 & 1.057 & \\
\hline [ECO3] & 5.92 & 1.042 & \\
\hline [ECO4] & 5.94 & 1.077 & \\
\hline \multicolumn{3}{|c|}{ Environmental Dimension (ENV) } & \\
\hline [ENV1] & 5.66 & 1.234 & \\
\hline [ENV2] & 5.61 & 1.261 & \\
\hline [ENV3] & 5.64 & 1.213 & \\
\hline [ENV4] & 5.60 & 1.234 & \\
\hline [ENV5] & 5.50 & 1.319 & \\
\hline \multicolumn{3}{|c|}{ Brand Awareness (BAW) } & \multirow{5}{*}{$\begin{array}{c}\text { Schivinski and Dabrowski } \\
\text { [105]; } \\
\text { Chen [106] }\end{array}$} \\
\hline [BAW1]" & 5.68 & 1.117 & \\
\hline [BAW2] & 5.66 & 1.120 & \\
\hline [BAW3] & 5.68 & 1.133 & \\
\hline [BAW4] & 5.66 & 1.098 & \\
\hline \multicolumn{3}{|c|}{ Brand Association (BAS) } & \multirow{6}{*}{ Aaker [73] } \\
\hline [BAS1] & 6.03 & 0.923 & \\
\hline [BAS2] & 6.07 & 0.912 & \\
\hline [BAS3] & 6.01 & 0.926 & \\
\hline [BAS4] & 6.01 & 0.983 & \\
\hline [BAS5] & 6.01 & 0.923 & \\
\hline \multicolumn{3}{|c|}{ Perceived Quality (PQ) } & \multirow{7}{*}{$\begin{array}{c}\text { Vukasović [107]; } \\
\text { Schivinski and Dabrowski } \\
{[105]}\end{array}$} \\
\hline [PQ1] & 5.74 & 1.119 & \\
\hline [PQ2] & 5.68 & 1.089 & \\
\hline [PQ3] & 5.72 & 1.166 & \\
\hline [PQ4] & 5.68 & 1.138 & \\
\hline [PQ5] & 5.67 & 1.174 & \\
\hline [PQ6] & 5.72 & 1.116 & \\
\hline
\end{tabular}


Table A1. Cont.

\begin{tabular}{|c|c|c|c|}
\hline $\begin{array}{l}\text { Research Constructs } \\
\text { and Items }\end{array}$ & Mean & SD & Adopted from \\
\hline \multicolumn{3}{|c|}{ Brand Loyalty (BL) } & \multirow{9}{*}{$\begin{array}{l}\text { Moreira et al. [108]; } \\
\text { Sahina et al. [109] }\end{array}$} \\
\hline [BL1] & 6.02 & 0.944 & \\
\hline [BL2] & 6.04 & 0.908 & \\
\hline [BL3] & 6.00 & 0.961 & \\
\hline [BL4] & 6.02 & 0.931 & \\
\hline [BL5] & 6.00 & 0.976 & \\
\hline [BL6] & 6.01 & 0.981 & \\
\hline [BL7] & 5.63 & 1.192 & \\
\hline [BL8] & 5.54 & 1.359 & \\
\hline \multicolumn{3}{|c|}{ Brand Credibility (BC) } & \multirow{5}{*}{$\begin{array}{c}\text { Erdem and Swait [44]; } \\
\text { Hur et al. [11]; } \\
\text { Dwivedi et al. [110] }\end{array}$} \\
\hline$[\mathrm{BC} 1]$ & 5.92 & 0.913 & \\
\hline [BC2] & 5.93 & 0.980 & \\
\hline [BC3] & 5.94 & 0.972 & \\
\hline$[\mathrm{BC} 4]$ & 5.95 & 0.949 & \\
\hline \multicolumn{3}{|c|}{ Brand Reputation (BR) } & \multirow{5}{*}{$\begin{array}{l}\text { Veloutsou and Moutinho } \\
\text { [111] }\end{array}$} \\
\hline [BR1] & 5.69 & 0.901 & \\
\hline [BR2] & 5.69 & 0.895 & \\
\hline [BR3] & 5.68 & 0.915 & \\
\hline [BR4] & 5.71 & 0.913 & \\
\hline \multicolumn{3}{|c|}{ Purchase Intention (PI) } & \multirow{4}{*}{$\begin{array}{l}\text { Kudeshia and Kumar [112]; } \\
\text { Schivinski and Dabrowski } \\
\text { [105]; } \\
\text { Yoo et al. [113]; Shukla [114] }\end{array}$} \\
\hline [PI1] & 5.69 & 0.873 & \\
\hline [PI2] & 5.69 & 0.957 & \\
\hline [PI3] & 5.73 & 0.940 & \\
\hline
\end{tabular}

\section{References}

1. Foroudi, P. Influence of brand signature, brand awareness, brand attitude, brand reputation on hotel industry's brand performance. Int. J. Hosp. Manag. 2018, 76, 271-285. [CrossRef]

2. Kim, S.; Lee, H. The effect of CSR Fit and CSR authenticity on the brand attitude. Sustainability 2019, 12, 275. [CrossRef]

3. Agudelo, M.A.L.; Jóhannsdóttir, L.; Davídsdóttir, B. A literature review of the history and evolution of cor-porate social responsibility. Int. J. Corp. Soc. Responsib. 2019, 4, 1.

4. Steurer, R.; Langer, M.; Konrad, A.; Martinuzzi, A. Corporations, stakeholders and sustainable development I: A theoretical exploration of business-Society relations. J. Bus. Ethics 2005, 61, 263-281. [CrossRef]

5. Piercy, N.F.; Lane, N. Corporate social responsibility: Impacts on strategic marketing and customer value. Mark. Rev. 2009, 9, 335-360. [CrossRef]

6. Zayyad, H.M.A.; Obeidat, Z.M.; Alshurideh, M.T.; Abuhashesh, M.; Maqableh, M.; Masa'deh, R. Corporate social responsibility and patronage intentions: The mediating effect of brand credibility. J. Mark. Commun. 2020, 27, 510-533. [CrossRef]

7. Organic Monitor. Strategic Insights: CSR \& Sustainability in the Beauty Industry. 2010. Available online: http://www. organicmonitor.com/709160.htm. (accessed on 6 March 2021).

8. McDougall, A. CSR and Sustainability Key to Improving Company Image in Cosmetics. 2010. Available online: http://www. cosmeticsdesign-europe.com/MarketTrends/CSR-and-sustainability-key-to-improving-company-image-in-cosmetics. (accessed on 6 March 2021).

9. Baalbaki, S.; Guzmán, F. A consumer perceived consumer-based brand equity scale. J. Brand Manag. 2016, 23, 229-251. [CrossRef]

10. Lai, C.S.; Chiu, C.J.; Yang, C.F.; Pai, D.C. The effects of corporate social responsibility on brand performance: The mediating effect of industrial brand equity and corporate reputation. J. Bus. Ethics 2010, 95, 457-469. [CrossRef]

11. Hur, W.M.; Moon, T.W.; Jun, J.K. The role of perceived organizational support on emotional labor in the airline industry. Int. J. Contemp. Hosp. Manag. 2013, 25, 105-123. [CrossRef] 
12. Singh, A.; Verma, P. How CSR Affects Brand Equity of Indian Firms? Glob. Bus. Rev. 2017, 18, S52-S69. [CrossRef]

13. Javed, M.; Rashid, M.A.; Hussain, G.; Ali, H.Y. The effects of corporate social responsibility on corporate reputation and firm financial performance: Moderating role of responsible leadership. Corp. Soc. Responsib. Environ. Manag. 2020, 27, 1395-1409. [CrossRef]

14. Chen, X.; Kelly, T.F. B-Corps-A growing form of social enterprise: Tracing their progress and assessing their performance. J. Leadersh. Organ. Stud. 2015, 22, 102-114. [CrossRef]

15. Rothenhoefer, L.M. The impact of CSR on corporate reputation perceptions of the public-A configurational multi-time, multisource perspective. Bus. Ethics Eur. Rev. 2019, 28, 141-155. [CrossRef]

16. Vishwanathan, P.; van Oosterhout, H.J.; Heugens, P.P.; Duran, P.; van Essen, M. Strategic CSR: A Concept Building Meta-Analysis. J. Manag. Stud. 2019, 57, 314-350. [CrossRef]

17. Pecot, F.; Merchant, A.; Valette-Florence, P.; De Barnier, V. Cognitive outcomes of brand heritage: A signaling perspective. J. Bus. Res. 2018, 85, 304-316. [CrossRef]

18. Vogel, D.J. Is there a market for virtue?: The business case for corporate social responsibility. Calif. Manag. Rev. 2005, 47, 19-45.

19. Morgan, R.M.; Hunt, S.D. The commitment-trust theory of relationship marketing. J. Mark. 1994, 58, 20-38. [CrossRef]

20. Martínez, P.; Rodriguez del Bosque, I. CSR and consumer loyalty: The roles of trust: Customer identification with the company and satisfaction. Int. J. Hosp. Manag. 2013, 35, 89-99. [CrossRef]

21. Hur, W.-M.; Kim, H.; Woo, J. How CSR Leads to Corporate Brand Equity: Mediating Mechanisms of Corporate Brand Credibility and Reputation. J. Bus. Ethics 2014, 125, 75-86. [CrossRef]

22. Vera-Martínez, J.; Alvarado-Herrera, A.; Currás-Pérez, R. Do Consumers Really Care about Aspects of Corporate Social Responsibility When Developing Attitudes toward a Brand? J. Glob. Mark. 2021, 1-15. [CrossRef]

23. Ben Ammar, H.; Naoui, F.B.; Zaiem, I. The influence of the perceptions of corporate social responsibility on trust toward the brand. Int. J. Manag. Account. Econ. 2015, 2, 499-516.

24. Spence, M. Signaling in Retrospect and the Informational Structure of Markets. Am. Econ. Rev. 2002, 92, 434-459. [CrossRef]

25. Walker, K. A Systematic Review of the Corporate Reputation Literature: Definition, Measurement, and Theory. Corp. Reput. Rev. 2010, 12, 357-387. [CrossRef]

26. Boulding, W.; Kirmani, A. A consumer-side experimental examination of signaling theory: Do consumers perceive warranties as signals of quality? J. Consum. Res. 1993, 20, 111. [CrossRef]

27. Qasim, S.; Siam, M.R.; Sallaeh, S.B. The impact of CSR on consumers purchase intention: The mediating role of corporate reputation and moderating peers pressure. Int. J. Supp. Chain Manag. 2017, 6, 239-245.

28. Pérez-Cornejo, C.; Quevedo-Puente, E.; Delgado-García, J.B. Reporting as a booster of the corporate social performance effect on corporate reputation. Corp. Soc. Responsib. Environ. Manag. 2020, 27, 1252-1263. [CrossRef]

29. Aguilera-Caracuel, J.; Guerrero-Villegas, J. How corporate social responsibility helps MNEs to improve their reputation. the moderating effects of geographical diversification and operating in developing regions. Corp. Soc. Responsib. Environ. Manag. 2017, 25, 355-372. [CrossRef]

30. Park, E. Corporate social responsibility as a determinant of corporate reputation in the airline industry. J. Retail. Consum. Serv. 2019, 47, 215-221. [CrossRef]

31. Lin, C.P.; Tsai, Y.H.; Chiu, C.K.; Liu, C.P. Forecasting the purchase intention of IT product: Key roles of trust and environmental consciousness for IT firms. Technol. Forecast. Soc. Chang. 2015, 99, 148-155. [CrossRef]

32. Martínez, P.; Nishiyama, N. Enhancing customer-based brand equity through CSR in the hospitality sector. Int. J. Hosp. Tour. Adm. 2017, 20, 329-353. [CrossRef]

33. Kennedy, S. Nurturing corporate images. Eur. J. Mark. 1977, 11, 120-164. [CrossRef]

34. Marin, L.; Ruiz, S.; Rubio, A. The role of identity salience in the effects of corporate social responsibility on consumer behavior. J. Bus. Ethics 2009, 84, 65-78. [CrossRef]

35. Martínez, P.; Pérez, A.; del Bosque, I.R. Exploring the Role of CSR in the Organizational Identity of Hospitality Companies: A Case from the Spanish Tourism Industry. J. Bus. Ethics 2014, 124, 47-66. [CrossRef]

36. Velasco, B.; Quintana-García, C.A.; Marchante-Lara, M. Total quality management, corporate social responsibility and performance in the hotel industry. Int. J. Hosp. Manag. 2014, 41, 77-87. [CrossRef]

37. Brown, T.J.; Dacin, P.A. The company and the product: Corporate association and consumer product responses. J. Mark. 1997, 61, 68-84. [CrossRef]

38. Keller, K.L.; Lehmann, D.R. Brands and Branding: Research Findings and Future Priorities. Mark. Sci. 2006, 25, 740-759. [CrossRef]

39. Zhang, L. How effective are your CSR messages? The moderating role of processing fluency and construal level. Int. J. Hosp. Manag. 2014, 41, 56-62. [CrossRef]

40. He, Y.; Lai, K.K. The effect of corporate social responsibility on brand loyalty: The mediating role of brand image. Total Qual. Manag. Bus. Excel. 2012, 25, 249-263. [CrossRef]

41. Shobri, M.; Diyana, N.; Lennora, P. Building guest loyalty: The role of guest based brand equity and guest experience in resort hotel industry. Adv. Sci. Lett. 2015, 21, 1605-1609. [CrossRef]

42. Del Barrio-García, S.; Prados-Peña, M.B. Do brand authenticity and brand credibility facilitate brand equity? The case of heritage destination brand extension. J. Destin. Mark. Manag. 2019, 13, 10-23. [CrossRef] 
43. Spry, A.; Pappu, R.; Cornwell, T.B. Celebrity endorsement, brand credibility and brand equity. Eur. J. Mark. 2011, 45, 882-909. [CrossRef]

44. Erdem, T.; Swait, J. Brand credibility, brand consideration and choice. J. Consum. Res. 2004, 31, 191-198. [CrossRef]

45. Mathew, V.; Ali, R.T.M.; Thomas, S. Loyalty intentions: Does the effect of commitment, credibility and awareness vary across consumers with low and high involvement? J. Indian Bus. 2014, 6, 213-230. [CrossRef]

46. Rifi, A.; Mostafa, R.B. Brand credibility and customer-based brand equity: A service recovery perspective. J. Financ. Serv. Mark. 2021, 1-16. [CrossRef]

47. Algammash, F.A. The effects of brand image, brand trust, brand credibility on customers' WOM communication. Int. J. Econ. Commer. Manag. 2020, 8, 81-94.

48. Chinomona, R. Brand communication, brand image and brand trust as antecedents of brand loyalty in Gauteng Province of South Africa. Afr. J. Econ. Manag. Stud. 2016, 7, 124-139. [CrossRef]

49. Baek, T.H.; Kim, J.; Yu, J.H. The differential roles of brand credibility and brand prestige in consumer brand choice. Psychol. Mark. 2010, 27, 662-678. [CrossRef]

50. Fatma, M.; Khan, I.; Rahman, Z. CSR and consumer behavioral responses: The role of customer-company identification. Asia Pac. J. Mark. Logist. 2018, 30, 460-477. [CrossRef]

51. Isaksson, L.; Kiessling, T.; Harvey, M. Corporate social responsibility: Why bother? Organ. Dyn. 2014, 43, 64-72. [CrossRef]

52. Song, H.; Ruan, W.; Park, Y. Effects of service quality, corporate image, and customer trust on the corporate reputation of airlines. Sustainability 2019, 11, 3302. [CrossRef]

53. Pineiro-Chousa, J.; Vizcaíno-González, M.; López-Cabarcos, M. Reputation, Game Theory and Entrepreneurial sustainability. Sustainability 2016, 8, 1196. [CrossRef]

54. Šontaitè-Petkevičienè, M. CSR reasons, practices and impact to corporate reputation. Procedia-Soc. Behav. Sci. 2015, 213, 503-508. [CrossRef]

55. Bianchi, E.; Bruno, J.M.; Sarabia-Sanchez, F.J. The impact of perceived CSR on corporate reputation and purchase intention. Eur. J. Manag. Bus. Econ. 2019, 28, 206-221. [CrossRef]

56. LaMastra, C. Corporate Social Responsibility Strategy to Repair Brand Reputation. American University. 2014. Available online: http:/ /hdl.handle.net/1961/auislandora:10367 (accessed on 6 March 2021).

57. Jeng, S.-P. The influences of airline brand credibility on consumer purchase intentions. J. Air Transp. Manag. 2016, 55, 1-8. [CrossRef]

58. Wang, X.; Yang, Z. The effect of brand credibility on consumers' brand purchase intention in emerging economies: The moderating role of brand awareness and brand image. J. Glob. Mark. 2010, 23, 177-188. [CrossRef]

59. Afzali, H.; Kim, S.S. Consumers' responses to corporate social responsibility: The mediating role of CSR authenticity. Sustainability 2021, 13, 2224. [CrossRef]

60. David, M.C.; Monica, F.; Estrella, D.; Silvia, R. Exploring relationships among brand credibility, purchase intention and social media for fashion brands: A conditional mediation model. J. Glob. Fash. Mark. 2018, 9, 237-251.

61. Bougoure, U.S.; Russell-Bennett, R.; Fazal-E-Hasan, S.; Mortimer, G. The impact of service failure on brand credibility. J. Retail. Consum. Serv. 2016, 31, 62-71. [CrossRef]

62. Qalati, S.A.; Yuan, L.W.; Jamali, A.B.; Kwabena, G.W.; Erusalkina, D. Brand equity and mediating role of brand reputation in hospitality industry of Pakistan. J. Bus. Manag. 2019, 1, 1-11.

63. Foroudi, P.; Yub, Q.; Guptac, S.; Foroudi, M.M. Enhancing university brand image and reputation through customer value co-creation behavior. Technol. Forecast. Soc. Chang. 2019, 138, 218-227. [CrossRef]

64. Foroudi, P.; Melewar, T.C.; Gupta, S. Linking corporate logo, corporate image, and reputation: An examina-tion of consumer perceptions in the financial setting. J. Bus. Res. 2014, 67, 2269-2281. [CrossRef]

65. Han, S.; Nguyen, B.; Lee, T. Consumer-based chain restaurant brand equity, brand reputation. Int. J. Hosp. Manag. 2015, 50, 84-93. [CrossRef]

66. Ramzan, I.; Ahmad, N. Factors of Restaurant Brand Equity and Their Impact on Brand Reputation. J. Mark. Consum. Res. 2018, 46, 33-41.

67. Gatti, L.; Caruana, A.; Snehota, I. The role of corporate social responsibility, perceived quality and corporate reputation on purchase intention: Implications for brand management. J. Brand Manag. 2012, 20, 65-76. [CrossRef]

68. Seo, E.-J.; Park, J.-W. A Study on the Impact of Airline Corporate Reputation on Brand Loyalty. Int. Bus. Res. 2016, 10, 59. [CrossRef]

69. Loureiro, S.M.C.; Sarmento, E.; le Bellego, G. The effect of corporate brand reputation on brand attachment and brand loyalty: Automobile sector. Cogent Bus. Manag. 2017, 4, 2-10. [CrossRef]

70. Sozer, E.G.; Civelek, M.E.; Kara, A.S. The effect of consumer based brand equity on brand reputation. Int. J. Eurasia Soc. Sci. 2017, 8,17 .

71. Aydın, G.; Ulengin, B. Effect of consumer-based brand equity on purchase intention: Considering socioeco-nomic status and gender as moderating effects. J. Euromark. 2015, 24, 107-119. [CrossRef]

72. Bashir, M.A.; Syed, M.F.; Masood, H.; Waseem, A.S. Impact of brand equity on consumer brand preference and brand purchase intention. IBT J. Bus. Stud. 2019, 15, 138-148. [CrossRef]

73. Aaker, D.A. Managing Brand Equity: Capitalizing on the Value of a Brand Name; The Free Press: New York, NY, USA, 1991. 
74. Keller, K.L. Conceptualizing, measuring, and managing customer-based brand equity. J. Mark. 1993, 57, 1-22. [CrossRef]

75. Wong, T.; Wickham, M. An examination of Marriott's entry into the Chinese hospitality industry: A Brand Equity perspective. Tour. Manag. 2015, 48, 439-454. [CrossRef]

76. Liu, M.T.; Wong, I.A.; Tseng, T.-H.; Chang, A.W.-Y.; Phau, I. Applying consumer-based brand equity in luxury hotel branding. J. Bus. Res. 2017, 81, 192-202. [CrossRef]

77. Le, P.V.H.; Nguyen, G.T.; Phung, H.T.T.; Ho, T.; Phan, N.T. The relationship between brand equity and in-tention to buy: The case of convenience stores. Interdepend. J. Manag. Prod. 2020, 11, 434-449.

78. Hunt, S.D. The ethics of branding, customer-brand relationships, brand-equity strategy, and branding as a societal institution. J. Bus. Res. 2018, 95, 408-416. [CrossRef]

79. Gunawardane, N.R. Impact of Brand Equity towards Purchasing Desition: A Situation on Mobile Telecommuni-cation Services of Sri Lanka. J. Mark. Manag. 2015, 3, 100-117. [CrossRef]

80. Troiville, J.; Hair, J.F.; Cliquet, G. Definition, conceptualization and measurement of consumer-based retailer brand equity. J. Retail. Consum. Serv. 2019, 50, 73-84. [CrossRef]

81. Maden, C.; Arıkan, E.; Telci, E.; Kantur, D. Linking Corporate Social Responsibility to corporate reputation: A study on understanding behavioral consequences. Proced. Soc. Behav. Sci. 2012, 58, 655-664. [CrossRef]

82. Agmeka, F.; Wathoni, R.N.; Santoso, A.S. The influence of discount framing towards brand reputation and brand image on purchase intention and actual behavior in e-commerce. Proced. Comput. Sci. 2019, 161, 851-858. [CrossRef]

83. Jung, N.Y.; Seock, Y.-K. The impact of corporate reputation on brand attitude and purchase intention. Fash. Text. 2016, 3, 20. [CrossRef]

84. Barney, J. Firm resources and sustained competitive advantage. J. Manag. 1991, 17, 99-120. [CrossRef]

85. Barney, J.B.; Ketchen, D.J.; Wright, M. The Future of Resource-Based Theory: Revitalization or Decline? J. Manag. 2011, 37, 1299-1315. [CrossRef]

86. Barney, J.B. Is the resource-based view a useful perspective for strategic management research. Acad. Manag. Rev. 2001, 26, 41-54.

87. Freeman, R.E. Strategic Management: A Stakeholder Approach; Pitman: Boston, MA, USA, 1984.

88. Akar, R.; Presidnet Cyprus Turkish Journalist Union, Nicosia, Cyprus. Personal communication, 12 July 1996.

89. Marcoulides, G.A.; Saunders, C. PLS: A Silver Bullet? MIS Q. 2006, 30, 4-8. [CrossRef]

90. Kerlinger, F.N.; Lee, H.B. Foundations of Behavioral Research; Harcourt College Publishers: Orlando, FL, USA, 2000.

91. Brislin, R.W. Back-Translation for Cross-Cultural Research. J. Cross-Cult. Psychol. 1970, 1, 185-216. [CrossRef]

92. Fornell, C.; Larcker, D.F. Structural equation models with unobservable variables and measurement error: Algebra and statistics. J. Mark. Res. 1981, 18, 382-388. [CrossRef]

93. Cohen, J. Statistical Power Analysis for the Behavioral Sciences; Academic Press: New York, NY, USA, 1988 ; p. 54.

94. Hair, J.F., Jr.; Hult, G.T.M.; Ringle, C.M.; Sarstedt, M. A Primer on Partial Least Squares Structural Equation Modeling (PLS-SEM); Sage Publications: Thousand Oaks, CA, USA, 2016.

95. Garson, G.D. Partial Least Squares: Regression and Structural Equation Models; Statistical Associates Publishers: Asheboro, NC, USA, 2016.

96. Hair, J.F., Jr.; Hult, G.T.M.; Ringle, C.M.; Sarstedt, M. A Primer on Partial Least Squares Structural Equation Modeling (PLS-SEM), 2nd ed.; Sage Publications: Thousand Oaks, CA, USA, 2017.

97. Zhao, X.; Lynch, J.G., Jr.; Chen, Q. Reconsidering Baron and Kenny: Myths and truths about mediation analysis. J. Consum. Res. 2010, 37, 197-206. [CrossRef]

98. Hung-Baesecke, C.J.F.; Chen, Y.R.R.; Boyd, B. Corporate social responsibility, media source preference, trust, and public engagement: The informed public's perspective. Pub. Relat. Rev. 2016, 42, 591-599. [CrossRef]

99. Carroll, A.B. The pyramid of corporate social responsibility: Toward the moral management of organizational stakeholders. Bus. Horiz. 1991, 34, 39-48. [CrossRef]

100. Sharma, S.; Henriques, I. Stakeholder influences on sustainability practices in the Canadian forest products industry. Strat. Manag. J. 2004, 26, 159-180. [CrossRef]

101. Aguinis, H. Organizational responsibility: Doing good and doing well. In APA Handbook of Industrial and Organizational Psychology: Maintaining, Expanding, and Contracting the Organization; Zedeck, S., Ed.; American Psychological Association: Washington, DC, USA, 2011; Volume 3, pp. 855-879.

102. Dabic, M.; Colovic, A.; LaMotte, O.; Painter, M.; Brozovic, S. Industry-specific CSR: Analysis of 20 years of research. Eur. Bus. Rev. 2016, 28, 250-273. [CrossRef]

103. Fatma, M.; Rahman, Z.; Khan, I. Measuring consumer perception of CSR in tourism industry: Scale develop-ment and validation. J. Hosp. Tour. Manag. 2016, 27, 39-48. [CrossRef]

104. Park, E.; Han, T.; Kim, T.; Kwon, S.J.; Del Pobil, A.P. Economic and Environmental benefits of optimized hybrid renewable energy Generation Systems at Jeju National University, South Korea. Sustainability 2016, 8, 877. [CrossRef]

105. Schivinski, B.; Dabrowski, D. The Consumer-Based Brand Equity Inventory: Scale Construct and Validation; GUT FME Working Paper Series A; Gdańsk University of Technology: Gdańsk, Poland, 2014; Volume 4, p. 22.

106. Chen, P.Y.; Hitt, L. Brand awareness and price dispersion in electronic markets. In Proceedings of the International Conference on Information Systems, ICIS 2001, New Orleans, LA, USA, 16-19 December 2001; Volume 26. 
107. Vukasović, T. An empirical investigation of brand equity: A cross-country validation analysis. J. Glob. Mark. 2016, $29,251-265$. [CrossRef]

108. Moreira, A.C.; Fortes, N.; Santiago, R. Influence of sensory stimuli on brand experience, brand equity and purchase intention. J. Bus. Econ. 2017, 18, 68-83. [CrossRef]

109. Sahina, A.; Zehirb, C.; Kitapçib, H. The effects of brand experiences, trust and satisfaction on building brand loyalty; an empirical research on global brands. Procedia Soc. Behav. Sci. 2011, 24, 1288-1301. [CrossRef]

110. Dwivedi, A.; Nayeem, T.; Murshed, F. Brand experience and consumers' willingness-to-pay (WTP) a price premium: Mediating role of brand credibility and perceived uniqueness. J. Retail. Consum. Serv. 2018, 44, 100-107. [CrossRef]

111. Veloutsou, C.; Moutinho, L. Brand relationships through brand reputation and brand tribalism. J. Bus. Res. 2009, 62, 314-322. [CrossRef]

112. Kudeshia, C.; Kumar, A. Social eWOM: Does it affect the brand attitude and purchase intention of brands? Manag. Res. Rev. 2017, 40, 310-330. [CrossRef]

113. Yoo, B.; Donthu, N.; Lee, S. An examination of selected marketing mix elements and brand equity. J. Acad. Mark. Sci. 2000, 28, 195-211. [CrossRef]

114. Shukla, P. Impact of interpersonal influences, brand origin and brand image on luxury purchase intentions: Measuring interfunctional interactions and a cross-national comparison. J. World Bus. 2011, 46, 242-252. [CrossRef] 